\title{
EDITORIAL
}

\section{Face masks and COVID-19: don't let perfect be the enemy of good}

Benjamin J Cowling ${ }^{1,2}$, Gabriel M Leung ${ }^{1,2}$

1. WHO Collaborating Centre for Infectious Disease Epidemiology and Control, School of Public Health, LKS Faculty of Medicine, The University of Hong Kong, Hong Kong Special Administrative Region, China

2. Laboratory of Data Discovery for Health, Hong Kong Science and Technology Park, Hong Kong Special Administrative Region, China

Correspondence: Benjamin J Cowling (bcowling@hku.hk)

Citation style for this article:

Cowling Benjamin J, Leung Gabriel M. Face masks and COVID-19: don't let perfect be the enemy of good. Euro Surveill. 2020;25(49):pii=2001998. https://doi. org/10.2807/1560-7917.ES.2020.25.49.2001998

Article submitted on 26 Nov 2020 / accepted on o9 Dec 2020 / published on 10 Dec 2020

Whether to don face masks or facial coverings to prevent community spread of coronavirus disease 2019 (COVID-19) has perhaps been one of the most argued and divisive issues, initially between East Asia and the West and later within western countries. Even the World Health Organization (WHO) had prevaricated on the issue during the initial months of the pandemic until it advised governments to 'encourage the general public to wear masks in specific situations and settings as part of a comprehensive approach to suppress COVID19 transmission' in guidance issued in June 2020 [1].

To assess the appropriateness of masks as an intervention measure, it is important to first understand the aerobiology and modes of transmission of COVID-19. There is general agreement that transmission risk is increased with prolonged close contact. The question concerning longer-range aerosol transmission remains a subject of strong debate. Severe acute respiratory syndrome coronavirus 2 (SARS-CoV-2) RNA detection in aerosols has been reported in some retrospective case reviews $[2,3]$ and viable virus could be detected in laboratory experiments [4] and patient settings [5] as well as anecdotal reports such as a reported restaurant outbreak [6]. While definitive proof of aerosol transmission remains elusive, prominent scientists have advocated a precautionary approach to mitigate the risks of aerosol spread, noting in particular that the risk of aerosol transmission would be greatest at short range $[7,8]$.

Widespread use of face masks may reduce community transmission in two ways. First, through source control, since masks worn by persons who are infected and contagious can effectively reduce viral dissemination into the environment $[9,10]$. This can be particularly important in the context of pre-symptomatic transmission of COVID-19 [11,12]. Second, face masks can have an impact through protection of uninfected persons, since masks can effectively filter virus-laden particles from the air breathed in [13-15]. However, there are also caveats. Masks will not be worn $100 \%$ of the time - they will not generally be worn in households or in some social settings, and they will not be worn while eating. In addition, even when masks are worn, they should reduce the risk of transmission but they may not completely eliminate transmission. While most research on face masks has involved surgical type face masks, it should be presumed that reusable cloth masks could provide similar benefits if they have a sufficient number of layers and preferably a filter.

While there is mechanistic support for the effectiveness of face masks from laboratory-based studies, evidence from real-life studies can confirm whether mask policies could have an impact on community transmission. The highest quality of scientific evidence on the real-life efficacy or effectiveness of an intervention is provided by randomised controlled trials. A number of randomised trials of face masks have been done to prevent transmission of respiratory virus infections. For example, the 2019 WHO guidance on non-pharmaceutical interventions cited evidence from 14 randomised controlled trials that did not support a statistically significant effect on transmission of laboratory-confirmed influenza [16]. However, in that guidance, mechanistic evidence of the effectiveness of face masks was used as a basis for a recommendation for widespread mask use in the community in influenza epidemics/pandemics of high or extraordinarily high severity [16].

In this issue of Eurosurveillance, Brainard et al. reviewed 12 randomised trials and 21 observational studies of the effectiveness of face mask use against 
respiratory virus transmission [17]. The meta-analysis of randomised trials has similar findings to a number of earlier Cochrane reviews [18-21] and published systematic reviews and meta-analyses [22-37], namely that face mask interventions could probably reduce transmission by a small margin but not a large margin in the community. Brainard et al. estimate that masks reduce the risk of infection by around 6\% to $15 \%$ [17]. While randomised trials typically provide the highest quality of evidence on interventions, limitations of trials in face masks have included the lack of blinding, and adherence with the intervention leading to effect dilution.

It should be noted that widespread use of face masks in an epidemic will have greater community benefit through reducing contagiousness of infected persons in addition to protecting susceptible wearers. One recent study from Germany reports a $45 \%$ reduction in transmission through face mask use [38], although this study might have overestimated the impact of masks if other public health measures and behavioural changes occurred simultaneously. There is evidence that universal wearing of face masks has not been sufficient to control COVID-19 transmission and additional public health measures are required. For example, Hong Kong has experienced multiple community epidemics of COVID-19 despite universal face mask use since January 2020 [39]. That said, most large clusters accounting for a substantial proportion of the total case burden have occurred in places where masks are not worn, such as bars, restaurants, gyms, elderly homes and workers' dormitories [40], while within-household transmission is also a major contributor to overall case numbers.

While most face mask trials have aimed to prevent influenza virus or any respiratory virus transmission, the Danish Study to Assess Face Masks for the Protection Against COVID-19 Infection (DANMASK-19) trial has just reported on the efficacy of masks to prevent COVID-19 transmission [41]. In this trial, 6,024 adults were randomly assigned to a mask recommendation or a control group, and after 1 month the cumulative incidence of COVID-19 in the two groups was $1.8 \%$ and $2.1 \%$ respectively, with a point estimate of a $15 \%$ reduction in risk associated with the face mask recommendation. However, this small risk reduction was not statistically significant. Of note, the study had only been powered to identify a $50 \%$ or greater risk reduction. The results of this trial should thus not be interpreted as evidence that masks do not work, since the effect size reported is very consistent with the effects that would be expected based on previous meta-analyses including this new report by Brainard et al. [17] One concern about the trial by Bundgaard et al. is the use of serology to identify outcomes. Since participants were only followed up for one month [17], it is possible that some infections identified in serology at day 30 were actually infections that occurred before the intervention, leading to effect dilution.
In comparison to randomised trials, observational studies provide relatively less reliable information on the effects of interventions, particularly for an intervention such as face masks that are often combined with other protective measures or changes in behaviours. A recent meta-analysis of observational studies found that face mask use by those exposed to infected individuals in non-healthcare observational settings was associated with a $44 \%$ risk reduction of infection with severe acute respiratory syndrome coronavirus (SARS-CoV) in 2003 [31]. However, one of the three original studies that formed the summary statistic actually referred to mask use by visiting family members to hospitalised SARS-CoV patients in 2003, thus the exposure per se was healthcare related. In the same review, eye protection alone was estimated to provide $78 \%$ reduction in risk of SARS-CoV or Middle East Respiratory Syndrome coronavirus (MERS-CoV) infection [31], an effect size which appears highly implausible given that eyes are unlikely to be a major route of infection.

There are clear evidential gaps in the science of modes of COVID-19 transmission. Nevertheless, there is compelling evidence that masks can contribute to the control of COVID-19. Given that face masks are inexpensive in comparison to the other public health measures being used to control COVID-19, even a limited effect on transmission would justify their widespread use. In addition to recommending that people wear face masks in poorly ventilated, crowded settings or when community prevalence is high, some health authorities might even consider to recommend the practice in all settings when in company. The only caveat relates to potential diversion of scarce supplies for healthcare settings, in which case alternative forms of facial coverings that are made of appropriate materials should be considered [1].

\section{Conflict of interest}

None declared.

\section{References}

1. World Health Organization (WHO). Advice on the use of masks in the context of COVID-19. Geneva: WHO; 5 Jun 2020. Available from: https://apps.who.int/iris/bitstream/ handle/10665/332293/WHO-2019-nCov-IPC_Masks-2020.4eng.pdf? sequence $=1$ \&isAllowed $=y$

2. Guo ZD, Wang ZY, Zhang SF, Li X, Li L, Li C, et al. Aerosol and Surface Distribution of Severe Acute Respiratory Syndrome Coronavirus 2 in Hospital Wards, Wuhan, China, 2020. Emerg Infect Dis. 2020;26(7):1583-91. https://doi.org/10.3201/ eid2607.200885 PMID: 32275497

3. Chia PY, Coleman KK, Tan YK, Ong SWX, Gum M, Lau SK, et al. Detection of air and surface contamination by SARSCoV-2 in hospital rooms of infected patients. Nat Commun. 2020;11(1):2800. https://doi.org/10.1038/s41467-020-16670-2 PMID: 32472043

4. van Doremalen N, Bushmaker T, Morris DH, Holbrook MG, Gamble A, Williamson BN, et al. Aerosol and Surface Stability of SARS-CoV-2 as Compared with SARS-CoV-1. N Engl J Med. 2020;382(16):1564-7. https://doi.org/10.1056/NEJMc2004973 PMID: 32182409

5. Lednicky JA, Lauzardo M, Fan ZH, Jutla A, Tilly TB, Gangwar $M$, et al. Viable SARS-CoV-2 in the air of a hospital room with COVID-19 patients. Int J Infect Dis. 2020;100:476-82. https:// doi.org/10.1016/j.ijid.2020.09.025 PMID: 32949774 
6. Lu J, Gu J, Li K, Xu C, Su W, Lai Z, et al. COVID-19 Outbreak Associated with Air Conditioning in Restaurant, Guangzhou, China, 2020. Emerg Infect Dis. 2020;26(7):1628-31. https:// doi.org/10.3201/eid2607.200764 PMID: 32240078

7. Morawska L, Milton DK. It is Time to Address Airborne Transmission of COVID-19. Clin Infect Dis. 2020. PMID: 32628269

8. Tellier R, Li Y, Cowling BJ, Tang JW. Recognition of aerosol transmission of infectious agents: a commentary. BMC Infect Dis. 2019;19(1):101. https://doi.org/10.1186/s12879-0193707-y PMID: 30704406

9. Leung NHL, Chu DKW, Shiu EYC, Chan KH, McDevitt JJ, Hau $\mathrm{BJP}$, et al. Respiratory virus shedding in exhaled breath and efficacy of face masks. Nat Med. 2020;26(5):676-80. https:// doi.org/10.1038/S41591-020-0843-2 PMID: 32371934

10. Milton DK, Fabian MP, Cowling BJ, Grantham ML, McDevitt JJ. Influenza virus aerosols in human exhaled breath: particle size, culturability, and effect of surgical masks. PLoS Pathog. 2013;9(3):e1003205. https://doi.org/10.1371/journal. ppat.1003205 PMID: 23505369

11. He D, Zhao S, Lin Q, Zhuang Z, Cao P, Wang MH, et al. The relative transmissibility of asymptomatic COVID-19 infections among close contacts. Int J Infect Dis. 2020;94:145-7. https:// doi.org/10.1016/j.ijid.2020.04.034 PMID: 32315808

12. Ferretti L, Wymant C, Kendall M, Zhao L, Nurtay A, AbelerDörner L, et al. Quantifying SARS-CoV-2 transmission suggests epidemic control with digital contact tracing. Science. 2020;368(6491):eabb6936. https://doi.org/10.1126/science. abb6936 PMID: 32234805

13. Belkin NL. The evolution of the surgical mask: filtering efficiency versus effectiveness. Infect Control Hosp Epidemiol. 1997;18(1):49-57. https://doi.org/10.2307/30141964 PMID: 9013247

14. van der Sande M, Teunis P, Sabel R. Professional and homemade face masks reduce exposure to respiratory infections among the general population. PLoS One. 2008;3(7):e2618. https://doi.org/10.1371/journal.pone.0002618 PMID: 18612429

15. Davies A, Thompson KA, Giri K, Kafatos G, Walker J, Bennett A. Testing the efficacy of homemade masks: would they protect in an influenza pandemic? Disaster Med Public Health Prep. 2013;7(4):413-8. https://doi.org/10.1017/dmp.2013.43 PMID: 24229526

16. World Health Organization (WHO). Non-pharmaceutical public health measures for mitigating the risk and impact of epidemic and pandemic influenza. Annex: report of systematic literature reviews. Geneva: WHO. Oct 2019. Available from: https://www. who.int/influenza/publications/public_health_measures/ publication/en/

17. Brainard J, Jones N, Lake I, Hooper L, Hunter PR. Community use of facemasks and similar barriers to prevent respiratory illness such as COVID-19: a rapid scoping review. Euro Surveill. 2020;25(49):2000725. https://doi.org/10.2807/1560-7917. ES.2020.25.49.2000725

18. Jefferson T, Foxlee R, Del Mar C, Dooley L, Ferroni E, Hewak $B$, et al. Interventions for the interruption or reduction of the spread of respiratory viruses. Cochrane Database Syst Rev. 2007; (4):CDo06207. https://doi.org/10.1002/14651858. CDo06207.pub2 PMID: 17943895

19. Jefferson T, Del Mar C, Dooley L, Ferroni E, Al-Ansary LA, Bawazeer GA, et al. Physical interventions to interrupt or reduce the spread of respiratory viruses. Cochrane Database Syst Rev. 2010; (1):CDo06207. https://doi. org/10.1002/14651858.CDo06207.pub3 PMID: 20091588

20. Jefferson T, Del Mar CB, Dooley L, Ferroni E, Al-Ansary LA, Bawazeer GA, et al. Physical interventions to interrupt or reduce the spread of respiratory viruses. Cochrane Database Syst Rev. 2011; (7):CDo06207. https://doi. org/10.1002/14651858.CDo06207.pub4 PMID: 21735402

21. Jefferson T, Del Mar CB, Dooley L, Ferroni E, Al-Ansary LA, Bawazeer GA, et al. Physical interventions to interrupt or reduce the spread of respiratory viruses. Cochrane Database Syst Rev. 2020;11:CDo06207. PMID: 33215698

22. Jefferson T, Foxlee R, Del Mar C, Dooley L, Ferroni E, Hewak $B$, et al. Physical interventions to interrupt or reduce the spread of respiratory viruses: systematic review. BMJ. 2008;336(7635):77-80. https://doi.org/10.1136/ bmj.39393.510347.BE PMID: 18042961

23. Jefferson T, Foxlee R, Del Mar C, Dooley L, Ferroni E, Hewak B, et al. Cochrane Review: Interventions for the interruption or reduction of the spread of respiratory viruses. Evid Based Child Health. 2008;3(4):951-1013. https://doi.org/10.1002/ebch.291 PMID: 32313518

24. Jefferson T, Del Mar C, Dooley L, Ferroni E, Al-Ansary LA, Bawazeer GA, et al. Physical interventions to interrupt or reduce the spread of respiratory viruses: systematic review.
BMJ. 2009;339(sep21 1):b3675. http://dx.doi.org/ https://doi. org/10.1136/bmj.b3675 PMID:19773323

25. Cowling BJ, Zhou Y, Ip DK, Leung GM, Aiello AE. Face masks to prevent transmission of influenza virus: a systematic review. Epidemiol Infect. 2010;138(4):449-56. https://doi.org/10.1017/ S0950268809991658 PMID: 20092668

26. Bin-Reza F, Lopez Chavarrias V, Nicoll A, Chamberland ME. The use of masks and respirators to prevent transmission of influenza: a systematic review of the scientific evidence. Influenza Other Respir Viruses. 2012;6(4):257-67. https://doi. org/10.1111/j.1750-2659.2011.00307.X PMID: 22188875

27. Barasheed O, Alfelali M, Mushta S, Bokhary H, Alshehri J, Attar AA, et al. Uptake and effectiveness of facemask against respiratory infections at mass gatherings: a systematic review. Int J Infect Dis. 2016;47:105-11. https://doi.org/10.1016/j. ijid.2016.03.023 PMID: 27044522

28. Saunders-Hastings P, Crispo JAG, Sikora L, Krewski D. Effectiveness of personal protective measures in reducing pandemic influenza transmission: A systematic review and meta-analysis. Epidemics. 2017;20:1-20. https://doi. org/10.1016/j.epidem.2017.04.003 PMID: 28487207

29. Aggarwal N, Dwarakanathan V, Gautam N, Ray A. Facemasks for prevention of viral respiratory infections in community settings: A systematic review and meta-analysis. Indian J Public Health. 2020;64(6) Supplement;S192-200. https://doi. org/10.4103/ijph.IJPH_470_20 PMID: 32496254

30. Camargo MC, Martinez-Silveira MS, Lima AA, Bastos BP, Santos DLD, Mota SEC, et al. Effectiveness of the use of non-woven face mask to prevent coronavirus infections in the general population: a rapid systematic review. Cien Saude Colet. 2020;25(9):3365-76. https://doi.org/10.1590/141381232020259.13622020 PMID: 32876275

31. Chu DK, Akl EA, Duda S, Solo K, Yaacoub S, Schünemann HJ, et al. Physical distancing, face masks, and eye protection to prevent person-to-person transmission of SARS-CoV-2 and COVID-19: a systematic review and meta-analysis. Lancet. 2020;395(10242):1973-87. https://doi.org/10.1016/S0140 6736(20)31142-9 PMID: 32497510

32. Dugré N, Ton J, Perry D, Garrison S, Falk J, McCormack J, et al. Masks for prevention of viral respiratory infections among health care workers and the public: PEER umbrella systematic review. Can Fam Physician. 2020;66(7):509-17. PMID: 32675098

33. Liang M, Gao L, Cheng C, Zhou Q, Uy JP, Heiner K, et al. Efficacy of face mask in preventing respiratory virus transmission: $A$ systematic review and meta-analysis. Travel Med Infect Dis. 2020;36:101751. https://doi.org/10.1016/j.tmaid.2020.101751 PMID: 32473312

34. Long Y, Hu T, Liu L, Chen R, Guo Q, Yang L, et al. Effectiveness of $\mathrm{N}_{95}$ respirators versus surgical masks against influenza: A systematic review and meta-analysis. J Evid Based Med. 2020;13(2):93-101. https://doi.org/10.1111/jebm.12381 PMID: 32167245

35. Maclntyre CR, Chughtai AA. A rapid systematic review of the efficacy of face masks and respirators against coronaviruses and other respiratory transmissible viruses for the community, healthcare workers and sick patients. Int J Nurs Stud. 2020;108:103629. https://doi.org/10.1016/j. ijnurstu.2020.103629 PMID: 32512240

36. Wang MX, Gwee SXW, Chua PEY, Pang J. Effectiveness of Surgical Face Masks in Reducing Acute Respiratory Infections in Non-Healthcare Settings: A Systematic Review and MetaAnalysis. Front Med (Lausanne). 2020;7:564280. https://doi. org/10.3389/fmed.2020.564280 PMID: 33102503

37. Xiao J, Shiu EYC, Gao H, Wong JY, Fong MW, Ryu S, et al. Nonpharmaceutical Measures for Pandemic Influenza in Nonhealthcare Settings-Personal Protective and Environmental Measures. Emerg Infect Dis. 2020;26(5):967-75. https://doi. org/10.3201/eid2605.190994 PMID: 32027586

38. Mitze T, Kosfeld R, Rode J, Wälde K. Face masks considerably reduce COVID-19 cases in Germany. Proc Natl Acad Sci USA. 2020;202015954. https://doi.org/10.1073/pnas.2015954117 PMID: 33273115

39. Cowling BJ, Aiello AE. Public Health Measures to Slow Community Spread of Coronavirus Disease 2019. J Infect Dis. 2020;221(11):1749-51. https://doi.org/10.1093/infdis/jiaa123 PMID: 32193550

40. Adam DC, Wu P, Wong JY, Lau EHY, Tsang TK, Cauchemez S, et al. Clustering and superspreading potential of SARS-CoV-2 infections in Hong Kong. Nat Med. 2020;26(11):1714-9. https:// doi.org/10.1038/S41591-020-1092-0 PMID: 32943787

41. Bundgaard $H$, Bundgaard JS, Raaschou-Pedersen DET, von Buchwald C, Todsen T, Norsk JB, et al. Effectiveness of Adding a Mask Recommendation to Other Public Health Measures to Prevent SARS-CoV-2 Infection in Danish Mask Wearers : A Randomized Controlled Trial. Ann Intern Med. 2020;M20-6817. https://doi.org/10.7326/M20-6817 PMID: 33205991 
License, supplementary material and copyright

This is an open-access article distributed under the terms of the Creative Commons Attribution (CC BY 4.0) Licence. You may share and adapt the material, but must give appropriate credit to the source, provide a link to the licence and indicate if changes were made.

Any supplementary material referenced in the article can be found in the online version.

This article is copyright of the authors or their affiliated institutions, 2020. 